\title{
KRYZYS ZIEMIAŃSTWA W GALICJI WSCHODNIEJ NA PRZEŁOMIE XIX I XX WIEKU (DO 1914 ROKU)
}

\author{
Magdalena Semczyszyn \\ (1D) http://orcid.org/0000-0003-4933-4346 \\ Instytut Pamięci Narodowej, Oddział w Szczecinie
}

\section{ABSTRACT \\ THE LANDOWNERS' CRISIS IN EASTERN GALICIA AT THE TURN OF THE $20^{\text {TH }}$ CENTURY}

At the turn of the 20th century, a large number of landowners in Eastern Galicia experienced a deep crisis, which resulted from economic problems as well as from social and political conflicts inspired by civilizational changes occurring at the time. In addition to the economic crisis and the peasant and socialist movement, the growing Ukrainian national movement was a prominent source of landowners' problems. The fear of losing political and material advantage in Eastern Galicia determined the attitude of local Polish landowners towards Ukrainians. The article discusses both social and political circumstances that have influenced the crisis, as well as the condition the landowners have found themselves in and their attempts to overcome growing difficulties.

Keywords: landowners, Eastern Galicia, Ukrainian national movement, Polish-Ukrainian relations.

Słowa kluczowe: ziemiaństwo, Galicja Wschodnia, ukraiński ruch narodowy, relacje polsko-ukraińskie.

Na przełomie XIX i XX wieku spora część ziemiaństwa w Galicji Wschodniej przeżywała głęboki kryzys ${ }^{1}$. Powodem były zarówno problemy ekonomiczne, jak

1 Współczesna literatura dotycząca tego zagadnienia koncentruje się głównie na działalności politycznej konserwatystów wschodniogalicyjskich (tzw. podolaków), z którymi utożsamia się zazwyczaj ziemian z Galicji Wschodniej. Zob. np. A. Górski, Podolacy. Obóz polityczny i jego liderzy, Warszawa 2013; M. Ustrzycki, Pomiędzy konserwatyzmem a nacjonalizmem. Podolacy wobec kwestii narodowej na wsi wschodniogalicyjskiej na przetomie XIX i XX wieku (do 1908 r.), „Przegląd Wschodni” 1999, z. 3, s. 477-498; J. Skwara, Konserwatyści wschodniogalicyjscy-podolacy wobec kwestii ukraińskiej w okresie namiestnictwa Michała Bobrzyńskiego 1908-1913, „Rocznik Historyczno-Archiwalny” 1996, t. 11, s. 13-38; A. Wątor, Polityczna aktywność wschodniogalicyjskich konserwatystów w świetle stosunków polsko-ukraińskich w Galicji na przełomie XIX i XX wieku [w:] Polska-Ukraina: historia, 
i pozostające z nimi w ścisłym związku konflikty społeczno-polityczne, wypływające z ówczesnych przemian cywilizacyjnych. Utrwalony w pamiętnikach i literaturze pięknej sielankowy obraz życia na prowincji - pasmo rautów, polowań i karnawałów - przesłaniać zaczęło widmo utraty dotychczasowego stanu posiadania ${ }^{2}$. O ile w Galicji Zachodniej główną przyczyną kłopotów właścicieli majątków były kwestie ekonomiczne oraz postulaty wysuwane przez przedstawicieli ruchu ludowego i socjalistycznego, o tyle na wschodzie kraju koronnego na liście problemów znalazły się także kwestia narodowościowa i zagrożenie ze strony rosnących w siłę narodowców ukraińskich.

\section{KWESTIA NARODOWOŚCIOWA I STOSUNKI SPOŁECZNE W GALICJI WSCHODNIEJ}

W drugiej połowie XIX wieku Galicja Wschodnia obejmowała łącznie 48 z 72 powiatów kraju koronnego Galicji i Lodomerii. Podział na wschodnią i zachodnią Galicję nie został nigdy formalnie usankcjonowany, chociaż opierał się na pewnych regulacjach administracyjnych, a tradycjami sięgał rozbiorów3 ${ }^{3}$. Obszar Galicji Wschodniej pokrywał się w przybliżeniu z terenem jurysdykcji lwowskiego Sądu Apelacyjnego $\left(55337 \mathrm{~km}^{2}\right)^{4}$. Według spisu ludności z roku 1900 całą Galicję $\left(78496 \mathrm{~km}^{2}\right)$ zamieszkiwało ogółem 7316000 osób, z czego na zachodzie kraju $(23160$ km²) - 2502 000,

polityka, kultura. Materiaty międzynarodowej konferencji naukowej, red. S. Zabrowarny, SzczecinWarszawa 2003, s. 62-81; idem, Ziemianin-polityk Tadeusz Cieński 1856-1925. Z dziejów konserwatyzmu wschodniogalicyjskiego, Szczecin 1997; J. Tereszczenko, Галийький консерватизм в контексті Українсько-польських відносин в Австро-Угорщині (друга половина XIX-початок XX cm.), „Ucrainica-Polonica" 2007, t. 1, s. 21-36; M. Semczyszyn, Spoleczno-polityczne postawy ziemiaństwa wschodniogalicyjskiego w świetle lwowskiej „,Gazety Narodowej” (1886-1914) [w:] Spoleczeństwo polityka -kultura. Studia nad dziejami prasy w II Rzeczypospolitej, red. T. Sikorski, Szczecin 2006, s. $7-23$.

2 Zob. m.in. M. Rosco-Bogdanowicz, Wspomnienia, t. I-II, Kraków 1959; B. Longchamps de Berier, Ochrzczony na szablach powstańczych. Wspomnienia (1884-1918), Wrocław 1983.

3 Ziemie zagarnięte przez Austrię w wyniku pierwszego rozbioru nazywano Królestwem Galicji i Lodomerii (Galicja Wschodnia). Zachodnia część wraz z Krakowem została przyłączona w 1795 r. i do 1803 r. stanowiła osobny kraj koronny. Następnie połączono obie części, ale już w 1809 r. Galicja Zachodnia została włączona do Księstwa Warszawskiego, następnie z jej terytorium wydzielono Wolne Miasto Kraków, w 1846 r. inkorporowane do Austrii - formalnie jako Wielkie Księstwo Krakowskie. W latach 1849-1860 obwody zachodniogalicyjskie podlegały cesarsko-królewskiej komisji gubernialnej w Krakowie, która w 1854 r. została zamieniona na osobny rząd krajowy z prezydentem krajowym na czele. Na podstawie tego podziału w $1850 \mathrm{r}$. utworzono dwa sądy apelacyjne (drugiej instancji) w Krakowie i we Lwowie, a obszar ich oddziaływania nieformalnie nakreślił granicę między wschodnią a zachodnią częścią kraju, przebiegającą między Sanem a Wisłokiem.

4 F. Bujak, Galicya, t. I: Kraj, ludność, społeczeństwo, rolnictwo, Lwów-Warszawa 1908, s. 47-48. 
na wschodzie (55 $\left.337 \mathrm{~km}^{2}\right)$ - $4814000^{5}$. Dominował krajobraz rolniczy: tylko 20,5\% osób żyło w miastach.

Galicja była terenem mieszanym narodowościowo, zamieszkanym przez Polaków, Rusinów (u schyłku XIX w. coraz częściej zwanych Ukraińcami) ${ }^{6}$, Żydów, Ormian, Niemców i inne pomniejsze grupy narodowościowe ${ }^{7}$, przy czym wschód cechował się przewagą ludności ruskiej (greckokatolickiej), a zachód pozostawał pod dominacją ludności polskiej (rzymskokatolickiej) ${ }^{8}$. Analiza dostępnych materiałów statystycznych pozwala wyodrębnić pewne stałe tendencje. W 1900 roku na obszar Galicji Wschodniej przypadło 23,59\% osób wyznających wiarę rzymskokatolicką (1 136 060 $)^{9}$. Ludność ta była uważana przez ówczesnych statystyków (prof. Franciszka Bujaka, prof. Tadeusza Pilata, prof. Józefa Buzka) za Polaków. W Galicji Wschodniej dominowała „ruska narodowość" ${ }^{10}$. Na początku XX wieku spośród 3074000 wszystkich galicyjskich Rusinów aż 97,5\% zamieszkiwało Galicję Wschodnią (2 997 000). Polacy przeważali liczebnie w powiecie lwowskim, brzozowskim i jarosławskim. Czterdzieści powiatów można określić jako polskoruskie (z nieznaczną przewagą Rusinów), natomiast w Kossowie, Jaworowie, Turce, Dolinie, Śniatyniu i Bohorodczanach Polacy (łacinnicy) nie przekraczali 8,2\% ${ }^{11}$.

Trzecią co do wielkości grupę narodowościową (wyznaniową) w Galicji Wschodniej tworzyli Żydzi ${ }^{12}$. W 1869 roku stanowili 12,4\% ogółu ludności na tym terenie (425 000). W 1900 roku zamieszkiwało go już 619000 Żydów, a więc 76,3\%

5 T. Gąsowski, Austriackie spisy ludności z lat 1869-1910, „Przeszłość Demograficzna Polski” 1981, t. 13, s. 34; W. Rapacki, Ludność Galicji, Lwów 1874, s. 40-41.

6 Autorka przyjęła w artykule zasadę wymiennego posługiwania się terminami „Rusini” i „Ukraińcy", zgodnie z kontekstem źródłowym bądź też źródłowo potwierdzoną samoidentyfikacją (endoetnonimem) danych grup czy osób. Nie jest możliwe wyznaczenie konkretnej granicy czasowej, po której należałoby zastąpić jeden termin drugim. Zgodnie z przesłankami źródłowymi do schyłku XIX w. można ograniczyć się w zasadzie do używania terminu „Rusini”, jednak nazwa „Ukraińcy” również występuje w przekazach z badanego okresu.

7 Zob. J. Hoff, Mieszkańcy małych miast Galicji Wschodniej w okresie autonomicznym, Rzeszów 2005, s. 32-33; S. Piszczek, Ormianie w życiu politycznym Galicji w latach 1861-1914, „Przemyskie Zapiski Historyczne" R. 14/15, 2003/2005, s. 109-137.

8 Szerzej: J.P. Himka, Dimensions of a Triangle: Polish-Ukrainian-Jewish Relations in Austrian Galicia, „Polin: Studies in Polish Jewry” 2001, vol. 12: Focusing on Galicia: Jews, Poles and Ukrainians 1772-1918, s. 25-48.

9 S. Pawłowski, Ludność rzymsko-katolicka w polsko-ruskiej części Galicji, Lwów 1919, s. 11; T. Gąsowski, Austriackie spisy ludności..., s. 37; F. Stefczyk, Problem sejmowej reformy wyborczej w świetle statystyki ludnościowej i podatkowej, Lwów 1912, s. 10.

10 Za: S. Kasznica, M. Nadobnik, Najważniejsze wyniki spisu ludności i spisu zwierzą domowych wedtug stanu z 31 grudnia 1910 r., „Wiadomości Statystyczne o Stosunkach Krajowych” 1911, t. 24, z. 1, s. XXVII-XXVIII.

11 T. Pilat, Najważniejsze wyniki spisu ludności z 31 grudnia 1890, „Wiadomości Statystyczne o Stosunkach Krajowych" 1891, t. 13, s. 16-17. Wyliczenia dotyczące powiatowych miejscowości Galicji Wschodniej zob. J. Hoff, op. cit., s. 32-34, 160-167.

12 Szerzej zob. M. Soboń, Polacy wobec Żydów w Galicji doby autonomicznej w latach 1868-1914, Kraków 2011. 
z ogólnej liczby 811000 przypadającej na cały kraj koronny ${ }^{13}$. Żydzi zajmowali się głównie handlem i produkcją przemysłową, wykonywali także wolne zawody (adwokaci, lekarze). Ze względu na postępującą parcelację rosła także liczba żydowskich właścicieli ziemskich na Podolu galicyjskim: w 1873 roku było ich 289 (13\%), w 1902 roku - 438 na $2430(18 \%)^{14}$. Dodajmy, że żydowscy właściciele ziemscy wywoływali niechęć wśród polskich ziemian ze względu na odmienny sposób gospodarowania na roli, wyznanie oraz naturalny brak przywiązania do szlacheckiej tradycji ${ }^{15}$.

Mozaika narodowościowa Galicji Wschodniej pozwala lepiej zrozumieć słowa znanego publicysty z przełomu wieków Wilhelma Feldmana, który opisując większą własność na wschodzie kraju, przyrównał ją do wysp „rozrzuconych po morzu ludności ruskiej”"16. Wieś była zdecydowanie ruska (ukraińska), dwór - polski. Stąd też relacje polsko-ukraińskie na prowincji opierały się w dużej mierze na codziennych kontaktach między dziedzicem a wsią. Miały charakter pokoleniowy, wyrosły z tradycji szlacheckiej, patrymonialnej współpracy z ludem, jednak coraz silniej uwidoczniała się „klasowa przepaść” między obiema narodowościami. Brak właściwej warstwy średniej powodował, jak pisano na łamach konserwatywnej „Gazety Narodowej”: ,że w Galicji Wschodniej naprzeciw małego rolnika Rusina stał zawsze wielki Polak" ${ }^{\prime 17}$.

13 J. Buszko, The Consequences of Galician Autonomy after 1967, „Polin: Studies in Polish Jewry” 2001, vol. 12: Focusing on Galicia: Jews, Poles and Ukrainians 1772-1918, s. 86.

14 T. Gąsowski, From Austeria to the Manor: Jewish Landowners in Autonomous Galicia, „Polin: Studies in Polish Jewry" 2001, vol. 12: Focusing on Galicia: Jews, Poles and Ukrainians 1772-1918, s. 120-136; W. Lewicki, Nasze czy obce żywioly?, „Gazeta Narodowa”, 8 VI 1889; Większa własność ziemska, „Gazeta Narodowa”, 29 I 1901. Do znanych żydowskich ziemian należały rody: Kimelmanów, Koflerów, Jawetzów, Sommersteinów, Schonfeldów, Wittlinów i Rublów. F. Bujak, Rozwój gospodarczy Galicji 1772-1914, Lwów 1917, s. 44-45. Do lat 60. XIX w. Żydzi formalnie nie mogli nabywać majątków ziemskich (okólnik gubernialny z 29 III 1795 r.). Ustawa z 18 II 1860 r. zrównywała w prawach posiadania wykształconych lub będących w służbie wojskowej Żydów z chrześcijanami. M. Śliż, Galicyjscy Żydzi na drodze do równouprawnienia 1848-1914. Aspekt prawny procesu emancypacji Żydów w Galicji, Kraków 2006, s. 60-63. Zob. też wspomnienia żydowskiego ziemianina: O. Kofler, Żydowskie dwory. Wspomnienia z Galicji Wschodniej od początku XIX wieku do wybuchu I wojny światowej, Warszawa 1999.

15 Wzrastająca niechęć do żydowskich dworów dawała przeciwnikom politycznym argument o powszechnym antysemityzmie panującym wśród wschodniogalicyjskich ziemian. I. Daszyński, Pamiętniki, t. I, Warszawa 1957, s. 121; S. Wasylewski, Czterdzieści lat powodzenia. Przebieg mojego życia, Wrocław 1959, s. 202; K. Chłędowski, Pamiętniki, t. II, Kraków 1957, s. 115.

16 W. Feldman, Stronnictwa i programy polityczne w Galicji 1846-1906, t. I, Kraków 1907, s. $227-228$.

17 Galicya w cyfrach, „Gazeta Narodowa”, 18 V 1895. 


\section{ZIEMIAŃSTWO WSCHODNIOGALICYJSKIE - PORTRET ZBIOROWY}

W omawianym okresie w Galicji Wschodniej mieszkało około 2000 większych właścicieli ziemskich ${ }^{18}$. Około, ponieważ z roku na rok liczba ziemian malała. W 1880 roku na wschodzie kraju gospodarowało 2600 ziemian, w 1912 już tylko 2297 , przy czym wykluczając właścicieli żydowskich $-1833^{19}$. Nawet po dodaniu członków rodzin była to - w porównaniu z ogółem ludności Galicji - liczba znikoma, bo wynosząca około 12 000-15000 osób. Bez względu na obce etniczne pochodzenie wielu rodzin (ormiańskie i ruskie) właściciele ziemscy na ogół identyfikowali się z polskim dziedzictwem historyczno-kulturowym.

Większość ziemian mogła poszczycić się szlacheckim pochodzeniem, ale szlachta wschodniogalicyjska nie stanowiła jednolitej warstwy. Zróżnicowanie wewnątrz stanu wiązało się nie tylko z poziomem zamożności, piastowanymi urzędami i posiadanymi z racji tego wpływami, ale przede wszystkim z pochodzeniem i łączącą się z nim tytulaturą. Obok przedstawicieli staropolskich familii, takich jak Dzieduszyccy, Sierakowscy, Sapiehowie czy Zamoyscy, wśród szlachty znalazły się również postaci, których tytuły miały bardzo krótką i kontrowersyjną metrykę. Takim rodzinom udało się wkraść na szlacheckie wyżyny dzięki nadaniom i wykupie tytułów od chętnie szafującego nimi dworu austriackiego zaborcy.

Ziemianie wschodniogalicyjscy, których metryka szlachecka sięgała czasów przedrozbiorowych, byli przeważnie potomkami kolonizatorów przybyłych na Kresy w XVI-XVII wieku. Jedna z gałęzi znanego rodu hrabiów Dunin-Borkowskich rozpoczynała swój wywód genealogiczny od średniowiecznego rycerza z Borkowic na Sandomierszczyźnie. Cieńscy, Rayscy i Kraińscy pochodzili z dawnego województwa sieradzkiego, Cywińscy z Wielkopolski, Grocholscy z sandomierskiego i poznańskiego, Krasińscy z Mazowsza, Niezabitowscy z lubelskiego. Rodowód ruski miały rodziny Szeptyckich, Matkowskich, Wasilewskich, Mazarakich, hrabiów Czaykowskich i Dzieduszyckich ${ }^{20}$.

Wielu znanych ziemian, działaczy i polityków ery autonomicznej posiadało rodowód ormiański, to znaczy wywodziło się od zasiedlających tereny byłej Rzeczypospolitej kupców z Armenii. Na czasy austriackie przypadło najwięcej nobilitacji i indygenatów ormiańskich ${ }^{21}$. Szlachta ormiańska szybko asymilowała się z polską, przejmując od niej nie tylko sposób gospodarowania, ale także tradycję i kulturę.

18 Zgodnie z definicją ziemiaństwa autorstwa Wojciecha Roszkowskiego do grupy tej należy zaliczyć wszystkich właścicieli majątków pochodzenia szlacheckiego oraz rodziny, które przez małżeństwa i kontakty towarzyskie zdołały się z nią zasymilować. Za: M. Ustrzycki, Ziemianie polscy na Kresach 1864-1914. Świat wartości i postaw, Kraków 2006, s. 9.

19 E. Dubanowicz, Kurya wielkiej własności, Lwów 1913, s. 4.

20 H. Stupnicki, Herbarz polski i imion spis zastużonych w Polsce ludzi wszystkich stanów i czasów, ułożony porzqdkiem alfabetycznym na podstawie herbarza Niesieckiego i manuskryptów, t. I-III, Lwów 1855-1862; J. Dunin-Borkowski, Spis nazwisk szlachty polskiej, Lwów 1888.

${ }^{21}$ Nadania otrzymały m.in. znane rodziny: Abrahamowiczów, Romaszkanów, Torosiewiczów, Zachariasiewiczów, Bogdanowiczów, Krzeczunowiczów, Issakowiczów, Augustynowiczów. L. Teodorowicz, Nieco o heraldyce i rodach Ormian Polskich, Lwów 1925, s. 5-11. 
Mimo to obcy rodowód części rodów szlacheckich dawał przeciwnikom politycznym argument, który często podnosili w celu dyskredytowania wschodniogalicyjskiego ziemiaństwa. Wspomniany już Wilhelm Feldman w taki sposób charakteryzował położone na wschodzie majątki: „mało tu panów staropolskich, nigdzie zaś tyle, co tu arystokratów austriackich świeżej daty i bardzo świeżej daty. Feudałów, których ojcowie sprzedawali pieprz, pędzili woły do Ołomuńca i handlowali końmi na jarmarkach, lub rękawem obcierali twarze po największym przysmaku ormiańskim: tłustej baraninie" 22 .

\section{MAJĄTKI}

Główny wyznacznik statusu społecznego warstwy ziemiańskiej stanowiły majątki ziemskie. W 1888 roku ziemia zapisana w dawnej tabuli krajowej i księgach tabularnych sądów obwodowych obejmowała prawie 3200000 ha i stanowiła 40,32\% powierzchni Galicji, z czego 76\% obszaru własności tabularnej przypadało na wschodnią cześć kraju ${ }^{23}$. Po odjęciu tak zwanych dóbr martwej ręki (dóbr rządowych, biskupich, klasztornych itd.) pozostawało w rękach prywatnych 4771000 mórg (2 $745710 \mathrm{ha})^{24}$, podzielonych na grupy latyfundiów magnackich (633 050 ha), fideikomisów (majątki niepodzielne - 33340 ha), majątki ziemiańskie (2 055110 ha) i dobra drobnoszlacheckie (57000 ha $)^{25}$.

Latyfundia magnackie w 1888 roku stanowiły $20 \%$ całej własności tabularnej w Galicji. Do grupy latyfundystów należało wówczas 37 właścicieli majątków zajmujących obszar powyżej 5700 ha, a wśród nich między innymi Alfred hr. Potocki, Jakub hr. Potocki z Brzeżan, Stanisław hr. Badeni, Karol hr. Lanckoroński, Stanisław hr. Siemieński, Kalikst hr. Poniński, Tadeusz hr. Dzieduszycki ${ }^{26}$. Obok potomków znanych kresowych rodów wielkimi majątkami dysponowali również ziemianie, którzy zawarli odpowiedni mariaż (np. Tadeusz Cieński) lub zbili fortunę na interesach

22 W. Feldman, op. cit., s. 230.

23 T. Pilat, $O$ stosunkach własności tabularnej $w$ Galicji a $w$ szczególności w obwodzie sądowym tarnopolskim. Wykład na posiedzeniu XXIII Rady Ogólnej c.k. galicyjskiego Towarzystwa Gospodarczego, Lwów 1888, s. 3-10. Por. Skorowidz dóbr tabularnych w Galicyi z Wielkiem Księstwem Krakowskiem na podstawie najnowszych materiatów urzędowych, oprac. T. Pilat, Lwów 1890.

241 mórg austriacki odpowiadał 0,5755 ha.

25 T. Pilat, O stosunkach własności tabularnej..., s. 3-10. Szlachta zagrodowa (posiadająca gospodarstwa liczące poniżej 200 morgów ziemi) zamieszkiwała ok. 700 zaścianków na galicyjskim Podolu i wokół Lwowa. Na ogół nie utrzymywała ona stosunków towarzyskich z ziemiaństwem, a poprzez przejmowanie wschodniego obrządku ulegała ruszczeniu. Nadal jednak uważała się za klasę odrębną od kmieci i stanowiła poważne zaplecze wyborcze dla polskiego ziemiaństwa. K. Ślusarek, Włościańscy i niewtościańscy mieszkańcy wsi galicyjskiej w XIX wieku, „Zeszyty Naukowe Uniwersytetu Jagiellońskiego. Prace Historyczne" 1999, z. 126, s. 117-124.

26 W. Lewicki, op. cit. 
handlowych i bankowych (np. baronowie Romaszkanowie). Największe latyfundia leżały w powiecie buskim, gdzie zajmowały aż $77,5 \%$ obszaru (w tym $53 \%$ lasów) ${ }^{27}$. Ziemianie obok magnatów byli zaliczani do wielkiej własności ziemskiej. Jej stan posiadania zamykał się w przedziale od 200 mórg (115 ha) do 10000 mórg (5755 ha). Według powyższych wyliczeń (1888) ziemiaństwo stanowiło 64\% ogółu własności tabularnej, choć z roku na rok statystyki zmieniały się na niekorzyść tej warstwy. W poszczególnych powiatach Galicji Wschodniej ziemiaństwo posiadało przeciętnie od 32 do $53 \%$ ziemi uprawnej ${ }^{28}$. Wielkość pojedynczych majątków była zróżnicowana, jednak dla obszaru całej Galicji wynosiła średnio około 440 ha $^{29}$. Ziemianie posiadali przeważnie po kilka folwarków. Gdy sąsiadowały one ze sobą, tworzyły kompleksy dóbr w postaci kluczy. Przykładem mogą być Horodenka, Siemakowice i Biłka Romaszkanow, które razem obejmowały 3176 mórg (1810 ha) i mieściły na swoim terenie aż 30 karczem. Dodajmy, że horodelskie dobra baronów Romaszkanów uchodziły za wzorowe w skali całej Galicji ${ }^{30}$.

Największe i najlepiej prosperujące zespoły dóbr znajdowały się na żyznych ziemiach galicyjskiego Podola (w powiatach borszczowskim, zaleszczyckim, podhajeckim, brzeżańskim, tarnopolskim, trembowelskim, skałackim i zbaraskim). Ze względu na dominujące w tamtejszym krajobrazie łany pszenicy i żyta obszar ten nazywano „spichlerzem Galicji” ${ }^{31}$. „Mieć tam majątek - pisał Ludwik Jabłonowski znaczyło to samo, co mieć go nad Amurem" "32.

Pracę na roli wykonywano raczej w tradycyjny sposób, a wprowadzanie na szeroką skalę nowinek technicznych, takich jak siewniki, kosiarki, młockarnie i sieczkarnie parowe lub elektryczne, praktykowano głównie na terenach wielkich posiadłości ${ }^{33}$. Różnice w wielkości i urządzeniu majątków ziemiańskich były duże. Stąd też obok wyśmienicie administrowanych kresowych pałaców, gdzie dominował marmurowy przepych, istniały również podupadłe, zadłużone majątki, których właściciele - jak obrazowo, choć zapewne przesadnie wyraził się w swoich pamiętnikach Adam Rozwadowski o rodzinie Mazewskich z Woroniaków - „mieszkali w czworakach jak chłopi, a gości przyjmowali szampanem i jajecznicą naszpikowaną muchami”"34. W przypadku takich rodzin następowała najczęściej dalsza pauperyzacja, a jej członkowie przechodzili do grupy drobnoziemiańskiej lub migrowali do miast. Los taki

27 Zob. przykładowy wykaz latyfundiów: ibidem.

28 W 1903 r. w rękach chrześcijańskich właścicieli ziemskich było odpowiednio 31\% gospodarstw na Podolu; $53 \% \mathrm{w}$ powiecie skałackim, $47 \mathrm{w}$ powiecie husiatyńskim; $13 \% \mathrm{w}$ powiecie zaleszczyckim. J. Rozwadowski, Ruskie bezrobocie w 1902 roku. Uwagi o jego terenie, Lwów 1904, s. 63.

29 Ibidem, s. 51-58.

30 Ibidem, s. 66.

31 Stownik geograficzny Królestwa Polskiego i innych krain stowiańskich, t. II, Warszawa 1881, s. 459 .

32 L. Jabłonowski, Pamiętniki, Kraków 1963, s. 86. Zob. też: A. Mycielski, Chwile czasu minionego, Kraków 1976, s. 10.

33 P. Franaszek, Informator statystyczny do dziejów społeczno-gospodarczych Galicji. Rolnictwo w Galicji w dobie autonomii. Produkcja roślinna, cz. I, Kraków-Warszawa 1992, s. 262-284.

34 Zakład Narodowy im. Ossolińskich we Wrocławiu (dalej: ZNiO), Papiery Rozwadowskich, sygn. 15539 III, A. Rozwadowski, Pamiętnik. Kopa lat 1876-1939, k. 97. 
spotkał między innymi Zygmunta i Wacława Dzieduszyckich, właścicieli podolskich, którzy po stracie majątków przybrali chłopskie nazwisko Dziduch ${ }^{35}$.

\section{PRACA PUBLICZNA}

W drugiej połowie XIX wieku przedstawiciele ziemiaństwa coraz częściej porzucali życie na prowincji na rzecz kariery politycznej. Młodzi ziemianie zdobywali najpierw doświadczenie w radach powiatowych i gminnych, a następnie wykorzystywali je między innymi w urzędach krajowych i państwowych, a także na forum Sejmu Krajowego i austriackiej Rady Państwa. Dzięki odpowiedniemu wykształceniu i pozycji społecznej ziemiaństwo było główną siłą polityczną w autonomicznej Galicji. Przewagę tę - poza urodzeniem i kwalifikacjami - zawdzięczało przede wszystkim korzystnej (i niedemokratycznej) ordynacji wyborczej do ciał przedstawicielskich. Licząca niewiele ponad 2000 osób warstwa większych właścicieli ziemskich stanowiła jedynie $0,4 \%$ ogółu wyborców, lecz dzięki kurialnemu systemowi wyborczemu jej reprezentanci zajmowali ponad 65\% składu izby poselskiej. W 1883 roku wśród 150 posłów w Sejmie Krajowym 105 było większymi właścicielami ziemskimi (liczba ta powoli ulegała zmniejszeniu, ale jeszcze w 1906 r. na 159 posłów 81 zaliczało się do warstwy ziemiańskiej) ${ }^{36}$. Podobnie rzecz się miała w przypadku deputowanych do Rady Państwa. Przedstawiciele ziemiaństwa Galicji Wschodniej w okresie autonomicznym dominowali w polityce krajowej i państwowej, piastowali urzędy marszałków sejmu, prezesów Koła Polskiego w Wiedniu, ministrów, prezesów rad powiatowych i gminnych ${ }^{37}$. Do grona najbardziej znanych należeli między innymi prezes Koła Polskiego w Wiedniu Kazimierz hr. Grocholski (1815-1888), ekonomista Kornel Krzeczunowicz (1815-1881), c.k. ministrowie skarbu Julian Dunajewski (1821-1907) i Leon Biliński (1846-1923), filozof, a zarazem kolejny prezes Koła Polskiego i minister Wojciech hr. Dzieduszycki (1848-1909), namiestnik Leon hr. Piniński (1857-1938), c.k. minister dla Galicji Dawid Abrahamowicz (18391926) ${ }^{38}$, premier rządu austriackiego Kazimierz Badeni (1846-1909), c.k. minister spraw wewnętrznych Agenor Romuald Gołuchowski (1812-1875), jego syn, c.k. minister spraw zagranicznych Agenor Maria Gołuchowski (1849-1921).

Odchodzenie ziemian od gospodarowania na roli pociągało jednak za sobą także negatywne skutki. Praca poza majątkiem obniżała poziom gospodarowania, a zastępstwa administratorów lub oddawanie dóbr w dzierżawy prowadziły najczęściej do problemów finansowych dworów.

35 L. Jabłonowski, op. cit., s. 325.

36 M. Semczyszyn, Galicyjskie wybory. Działalność Centralnego Komitetu Wyborczego dla Galicji Wschodniej 1867-1906, Warszawa 2014, s. 98; E. Dubanowicz, op. cit., s. 4 i n.

37 Zob. W. Łazuga, Kalkulować... - Polacy na szczytach C.K. Monarchii, Poznań 2013.

38 D. Szymczak, Między Wiedniem, Lwowem a Siemianówką. Dawid Abrahamowicz w życiu polityczno-społecznym Galicji i monarchii habsburskiej [w:] Znani i nieznani dziewiętnastowiecznego Lwowa. Studia i materiały, t. 4, red. L. Michalska-Bracha, M. Przeniosło, Kielce 2014, s. 131-156. 


\section{Symptomy kryzysu ziemiaństwa. Problemy ekonomiczne}

Warunki prawne autonomii galicyjskiej sprzyjały ziemiaństwu. Dotyczyło to przede wszystkim stosunków na wsi, która pomimo zniesienia poddaństwa (1848) zachowała pewne relikty ustroju feudalnego. Ustawy drogowa, łowiecka i gminna oraz stosowne rozporządzenia o obszarach dworskich i reprezentacjach powiatowych (1865-1866) dostosowane zostały do potrzeb i wymogów właścicieli dworów, stanowiąc jednocześnie punkt wyjścia do roszczeń ze strony chłopów. Podobnie likwidacja serwitutów pastwiskowych i leśnych dostarczała powodów do konfliktów między dworem a wsią, zaś problemy z ich uregulowaniem ciągnęły się bardzo długo (1858-1890). Odpowiednie wybiegi prawne pozwalały obejść ziemiaństwu zniesione w latach 1875-1889 prawo propinacji, a odszkodowania indemnizacyjne i niska płaca dla robotników rolnych w części rekompensowały dawną korzyść z pańszczyzny. Majątek ziemski nadal spełniał dominującą rolę ekonomiczną na wsi ${ }^{39}$. Pomimo - wydawałoby się - sprzyjających warunków rozwoju dwory wschodniogalicyjskie borykały się jednak $\mathrm{z}$ wieloma problemami.

W drugiej połowie XIX wieku długi, parcelacje i sprzedaż majątków były zjawiskiem powszechnym w Galicji. Wiele dóbr marniało w wyniku źle prowadzonej administracji i oszustw dokonywanych przez rządców. Istotne znaczenie miały również przemiany ekonomiczne w Europie. W latach 70. XIX wieku konkurencja zboża amerykańskiego spowodowała znaczny spadek cen na rynku europejskim. Bieda na wsi wzmagała z kolei emigrację robotników rolnych z Galicji. Ponadto urządzenie majątków ziemiańskich nie nadążało za ówczesnymi przemianami przemysłowymi. Wielu właścicieli lekceważyło nowoczesne techniki uprawy roli oraz niedostatecznie dbało o przydomowy przemysł przetwórczy (młyny, gorzelnie, tartaki). Według ziemianina Bogusława Longchamps de Berier głównymi przyczynami upadków dóbr ziemiańskich były również: ,życie nad stan, rozpusta, alkohol, konie, karty i zła administracja" ${ }^{40}$. Ta gorzka opinia ma pewne uzasadnienie. Potwierdzają ją przypadki właścicieli przeciętnych, 600-morgowych majątków, którzy trwonili pieniądze na bale, egzotyczne polowania oraz kosztowne tytuły hrabiowskie i baronowskie. Niektórzy zaglądali też do kasyn, gdzie nierzadko przegrywali, tak jak na przykład Franciszek Rozwadowski, cały swój majątek ${ }^{41}$. Wreszcie parcelacje i spekulacyjna sprzedaż dóbr stanowiły źródło łatwych dochodów, dla których - jak się wyraził znany galicyjski ziemianin i racjonalizator rolnictwa Jerzy Turnau - „wielu ziemian dezerterowało z posterunków narodowych"42.

\footnotetext{
39 Według wyliczeń Jana Rozwadowskiego w pierwszych latach XX w. przeciętny 600-hektarowy folwark podolski był podstawą utrzymania dla 40 rodzin służby folwarcznej i domowej oraz 40 rodzin zarobkujących sezonowo. J. Rozwadowski, Obrona Ziemi. Odczyt wygłoszony w Związku Kół Ziemianek we Lwowie dnia 7 marca 1912 r., Kraków 1912, s. 14.

40 B. Longchamps de Berier, op. cit., s. 242.

41 ZNiO, Papiery Rozwadowskich, sygn. 15539 III, A. Rozwadowski, Pamiętnik. Kopa lat 18761939, k. 10.

42 Na dnie, „Gazeta Narodowa”, 24 XI 1907.
} 
W wyniku pogarszającej się sytuacji ekonomicznej ziemiaństwa majątki często zmieniały swoich właścicieli. Profesor Tadeusz Pilat, opracowując skorowidz galicyjskich dóbr tabularnych dla roku 1890, porównał nazwiska ówczesnych posiadaczy z wykazami z roku 1830. Okazało się, że mało rodzin zdołało utrzymać majątki w swoich rękach, część przekazano drogą dziedziczenia w linii żeńskiej, jednak większość przepadła w wyniku parcelacji lub sprzedaży. Dla przykładu, w powiatach zbaraskim, tarnopolskim, husiatyńskim i skałackim na 316 ciał tabularnych zmiana właściciela nastąpiła w 230 przypadkach ${ }^{43}$. W latach 1901-1907 co szósty majątek ziemski trafiał na sprzedaż. W 1912 roku ziemianin z Galicji Wschodniej Witold ks. Czartoryski na zebraniu kółek ziemian w Poznaniu w następujący sposób opisał efekt półwiekowych licytacji majątków: „ziemia nam się z rąk usuwa [...], dwory rozebrane na cegłę, lasy wycięte, z ogrodów odwieczne drzewa wyrąbane na sągi”"44.

Krótkotrwałym ratunkiem dla zagrożonej ziemi okazał się kredyt konsumpcyjny, a następnie hipoteczny, który niespłacony w terminie powodował nowe konwersje długów i mógł doprowadzić w ostateczności do parcelacji, sprzedaży lub przejścia majątku na własność wierzyciela. W ówczesnych realiach „każdy prawie szlachcic, właściciel ziemski brał pożyczkę" ${ }^{45}$ i przez to skala zadłużenia wschodniogalicyjskich majątków była ogromna. Dla przykładu w 1892 roku w powiecie kamioneckim długi miało $83 \%$ ciał tabularnych, w samborskim $-78 \%$, sokalskim $-80 \%$, podhajeckim $68 \%{ }^{46}$. W latach $1876-1885$ najwięcej przymusowych licytacji (razem 454) odbyło się w powiatach przemyskim, samborskim, tarnopolskim i stanisławskim ${ }^{47}$. Na ogół utrata majątków pociągała za sobą prawdziwe ludzkie dramaty ${ }^{48}$. W dodatku ponad połowa parcelacji w Galicji odbywała się na wschodzie, gdzie ziemia w $70 \%$ trafiała w ręce ukraińskich chłopów. Przeczyło to popularnej wśród ziemiaństwa idei, według której „parcelacja, wyswobadzając istniejący stan ziemiański z ekonomicznego upadku, pomnożyła go nowymi członkami i zabezpieczyła przyszłość tego stanu"49. Obawa przed przechodzeniem ziemi w ukraińskie ręce u progu XX wieku zyskała wydźwięk polityczny. Ze względu na pogłębiający się antagonizm polsko-ukraiński problemy etniczne zaczęły odgrywać na tym obszarze rolę pierwszoplanową. Część ziemiaństwa żywiła przekonanie, że oto wraz z nim zniknie na wsi wschodniogalicyjskiej „ostatni bastion polskości”.

43 T. Pilat, O stosunkach własności tabularnej..., s. 13-14.

44 W. Czartoryski, Kótka ziemian, Kórnik 1912, s. 5.

45 Ibidem, s. 6.

46 W. Ostrożyński, Galicyjskie Towarzystwo Kredytowe ziemskie. Jego powstanie i pótwiekowy rozwój, Lwów 1892, s. 218-219.

${ }^{47}$ F. Stefczyk, Licytacje sądowe większej posiadłości ziemskiej w Galicji 1876-1885, Kraków 1886, s. $10-13$.

48 W 1902 r. Seweryn Br. Brunicki, właściciel pokaźnego majątku w Zaleszczykach, popełnił samobójstwo z powodu opłakanego stanu finansowego związanego z nadużyciami w gorzelni zaleszczyckiej. Majątek był obciążony pożyczką Banku Hipotecznego na przeszło 2 miliony koron. Kronika, „Gazeta Narodowa”, 15 VIII 1902.

49 [b.t.], „Gazeta Narodowa”, 7 V 1886. 


\section{Kwestia narodowościowa}

Jeśli wierzyć słowom ziemianina Mariana Rosco-Bogdanowicza, do końca XIX wieku stosunki międzyetniczne na prowincji układały się na ogół poprawnie ${ }^{50}$. Właściciele wsi władali językiem ukraińskim i zwracali się w nim do chłopstwa, bogatsi budowali w swoich wsiach cerkwie, nierzadko sami byli wyznania greckokatolickiego bądź też uczestniczyli w liturgiach obu obrządków (m.in. Sapiehowie, Sanguszkowie, Szeptyccy, Baworowscy, Cywińscy, Dzieduszyccy, Potoccy) ${ }^{51}$. Rok gospodarowania na roli znaczyły dni odpoczynku w święta rzymskokatolickie i greckokatolickie ${ }^{52}$. Duchowni unickiego obrządku utrzymywali zażyłe stosunki z dworami. Właściciele dóbr często odgrywali rolę sędziów, próbowali łagodzić wiejskie spory, służyli radą i pomocą. Kandydując na posłów do Sejmu Krajowego lub austriackiej Rady Państwa w IV kurii (gmin wiejskich), ziemianie przedstawiali siebie zawsze jako reprezentantów (i rzeczników) ludu, a na zgromadzeniach przedwyborczych przemawiali do zgromadzonych włościan po ukraińsku ${ }^{53}$. Wielu ziemian znajdowało się pod prawdziwym urokiem ruskiego folkloru, na przykład znawca Huculszczyzny Włodzimierz hr. Dzieduszycki. Barwne, na poły mityczne wyobrażenie o Rusinach, o ich solidaryzmie z polską szlachtą, czerpano z poezji, dumek oraz powieści romantycznych i próbowano ten idylliczny obraz utrwalać w przekonaniu społeczeństwa. Nie był on jednak prawdziwy.

Wydaje się, że narodowościową dychotomię kresowego świata zaczęly zarysowywać zaniedbane kwestie ekonomiczne - zarzewie przyszłych konfliktów ${ }^{54}$. Druga połowa XIX wieku to jednak także okres kształtowania się ruskich (ukraińskich) nurtów politycznych, które podnosiły na forum publicznym postulaty odpowiednich koncesji w sferze kulturalnej, oświatowej i - wreszcie - także politycznej. Nowoczesna agitacja polityczna na prowincji galicyjskiej wywołała tendencje emancypacyjne wśród szerszych warstw społeczeństwa, dotąd niemych i biernych. To także okres, w którym wyłoniły się podstawy nowoczesnego nacjonalizmu opartego na kryterium etniczności. Na wzrost świadomości politycznej miały wpływ postulaty o charakterze narodowym, sprzeciwiające się polonocentrycznej wizji Galicji, takie jak równouprawnienie języka, szkolnictwa, dostępu do posad, proporcjonalność liczby mandatów sejmowych do liczby ludności danej narodowości, czy wreszcie roszczenia terytorialne, w tym wyartykułowane już w 1848 roku w kręgach ruskich

50 M. Rosco-Bogdanowicz, op. cit., t. I, s. 197. Por. B. Longchamps de Berier, op. cit., s. 223, J. Hoff, op. cit., s. 42-48; Z. Pucek, Więź społeczna w wielokulturowej Galicji, „Państwo i Społeczeństwo" R. 8, 2008, nr 1, s. 59-70.

51 ZNiO, Papiery Rozwadowskich, sygn. 15539 III, A. Rozwadowski, Pamiętnik. Kopa lat 18761939, k. 13; W. Dzieduszycki, Listy ze wsi, serya I, Lwów 1889, s. 342; M. Ustrzycki, Pomiędzy konserwatyzmem a nacjonalizmem..., s. 481.

52 Ziemianin Ilustrowany. Kalendarz poświęcony sprawom rolnictwa i ogrodnictwa krajowego na rok 1898 wydany przez pierwszy galicyjski Dom Dla Ziemian, Lwów 1898.

${ }_{53}$ Zob. m.in. wyjątki z przemówienia Dawida Abrahamowicza na wiecu wyborczym w okręgu IV kurii Lwów-Gródek-Jaworów. Sprawozdania wyborcze, „Dziennik Polski”, 3 VI 1885.

54 S. Głąbiński, Wspomnienia polityczne, Pelpin 1939, s. 42. 
hasło podziału Galicji na część zachodnią („mazurską”, polską) i wschodnią (ruską/ ukraińską). Retoryka polityczna oparta została na budowaniu nowych kontrastów. Na wsi stare „my - włościanie” i „oni - szlachta, ziemianie” zaczęło być zastępowane przez „my - Rusini/Ukraińcy” i „oni - Polacy”.

Większość ziemian lekceważyła te przemiany, wierząc w możliwość sąsiadowania z ludem ruskim na własnych zasadach, dlatego długo nie mogła pogodzić się z zaistnieniem u niego tendencji emancypacyjnych. Uważano, że ludność ruska wpisana była w historię i tradycje Rzeczpospolitej i nawet po zniesieniu pańszczyzny patrymonialną zależność między wsią a dziedzicem uznawano za naturalną: ziemiaństwo brało w opiekę ruski lud i służyło mu pomocą ${ }^{55}$. Ewentualne różnice sprowadzano do kwestii religijnych, powtarzając słowa ormiańskiego posła Emila Torosiewicza:

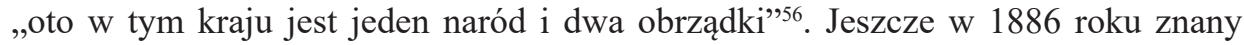
polityk i właściciel Jezupola, Wojciech hr. Dzieduszycki, zachęcał ziemian do nauki języka ruskiego, uzasadniając: , ,chcemy być tu uważani za Rusinów, pozostając zawsze Polakami" ${ }^{57}$. Naznaczona duchem romantyzmu przyjaźń do ludu mieściła się w ramach ziemiańskiego ,programu” opieki nad wsią, byle tylko ,jej nie wydzielać i nie nadwyrężać z całości spraw krajowych" ${ }^{58}$ oraz nie poddawać politycznym dyskusjom. Nawet ci nieliczni „podolacy”, którzy tak jak Wojciech hr. Dzieduszycki uznawali odrębność języka i folkloru ruskiego, skłaniali się ku ustępstwom jedynie w dziedzinie obyczajowości, nie polityki. Unikanie „ruskich” tematów stawało się jednak coraz trudniejsze. Tym bardziej że Galicja Wschodnia wybierała aż dwie trzecie reprezentacji Sejmu Krajowego ${ }^{59}$. Konserwatyści wschodniogalicyjscy nie umieli dostrzec tego problemu i dalecy byli od kompromisów.

U progu XX wieku w Galicji, poza partią moskalofilską, istniały już cztery partie narodowców ukraińskich (narodowi demokraci, socjaldemokraci, radykałowie, Katolicki Związek Rusko-Ludowy - KZRL). Wszystkie - poza konserwatystami z KZRL - stawiały bardzo wyraźne żądania socjalne, a także narodowościowe. Na wiecach ukraińskich radykałów pobrzmiewać zaczęło także hasło niepodległej Ukrainy oraz parcelacji ziemiańskich majątków pomiędzy ukraińskich chłopów. Wszystko to wpływało na poczucie zagrożenia właścicieli polskich dworów. Umasowienie partii ukraińskich spowodowały, że sąsiedztwo z Rusinami przestało nosić cechy prowincjonalnej sielanki. W 1906 roku na łamach konserwatywnej „Gazety Narodowej” pisano: „stykamy się codziennie oko w oko z tem społeczeństwem dla nas wrogiem, od nas różnem [...]. Ciemne masy ludowe ruskie posiadają dotąd jeszcze instynkty koczowników, pożądających nie dobrych i normalnych warunków pracy, lecz cudzych lasów i pastwisk” ${ }^{60}$ oraz: „niemal każdy dom Boży na wsi, gdzie ob-

55 Zob. R. Ludwikowski, Szkice na temat galicyjskich ruchów i myśli politycznej (1848-1892), Warszawa 1980, s. 128; K. Stauter-Halsted, The Nation in the Village: The Genesis of Peasant National Identity in Austrian Poland 1848-1914, New York 2004, s. 21-32.

56 Debata w sprawie ruskiej, „Gazeta Narodowa”, 5 I 1886.

57 Ibidem.

58 Ibidem.

59 S. Głąbiński, Ludność polska w Galicji Wschodniej, Lwów 1903, s. 226.

60 „Gazeta Narodowa”, 10 X 1906. 
szarnik ma do dziś ławkę kolektorską, niemal każda plebania fundowana przez jego ojców są dziś siedliskami zjadliwej i zawziętej agitacji, wrogiej przeciwko każdemu obszarnikowi, który jest w tym zuchwałym, że nie ustępuje z dworu"61.

\section{Krytyka ziemiaństwa ze strony przedstawicieli nowych ruchów społeczno-politycznych}

Schyłek wieku przyniósł na galicyjskiej prowincji także szerszy rezonans poglądów głoszonych przez działaczy socjalistycznych i ludowych ${ }^{62}$. Nowoczesna agitacja wywołała tendencje emancypacyjne wśród szerszych warstw społeczeństwa. Ważnym them pozostawały postulaty reformy wyborczej i jawna krytyka warstw uprzywilejowanych. Otwarciu na nowe prądy służyły także zjawiska cywilizacyjne: mozolne upowszechnianie oświaty, działalność społeczna i gospodarcza wielu towarzystw ukraińskich na prowincji, emigracja zarobkowa i uprzemysłowienie.

Słowa krytyki ze strony nowych oponentów politycznych w dużej mierze adresowane były do warstwy ziemiańskiej. Działacze ludowi, socjalistyczni i ukraińscy zarzucali jej próżniactwo, egoizm stanowy, służalczość wobec zaborcy, wstecznictwo, a przede wszystkim krytykowali konserwatywne rządy w kraju. Lider socjalistów Ignacy Daszyński twierdził wręcz, że władze wiedeńskie „wydzierżawiły ziemiaństwu Galicję jako prywatny folwark" ${ }^{63}$. Publicyści nie szczędzili właścicielom dworów pejoratywnych określeń, takich jak „,̇ubry kresowe”, „kasta obszarnicza”, „,magnateria w koncentracie”, „,mamuty”, ,grajzlernicy”, „,szlachecka banda” ${ }^{64}$. O tym, jak bardzo brutalna stawała się retoryka antyziemiańska, świadczą artykuły partyjnej prasy. Przykładowo w 1895 roku, gdy w wyborach do Sejmu Krajowego mandaty zdobyło 12 chłopów, redakcja socjalistycznego „Naprzód” zwycięstwo skomentowała następująco: „cieszy nas szczerze całkiem, że raz przecie dostała cięgi ta czarna chmura klerykalno-szlacheckiej szarańczy, która niszczy i wyzyskuje nasz lud" ${ }^{65}$. Sześć lat później na łamach socjalistycznego tygodnika „Podolanin” pisano o właścicielach dworów jeszcze ostrzej: „używają jednej z nami mowy, a mówią innym językiem, [...] żywią się najwstrętniejszym serwilizmem, są między nami i trupem cuchną"66"

Obóz konserwatywny bardzo żywo reagował na tego typu oskarżenia. Agitacja ruchu ludowego i ukraińskiego na wsi przywodziła na myśl widmo Jakuba Szeli67. Właściciel majątku Sadki, Mieczysław hr. Piniński, w broszurze poświęconej

61 Ibidem, 3 VIII 1907.

62 Ruch ludowy rozwijał się w Galicji od lat 70. XIX w. Stronnictwo Ludowe powstało w $1895 \mathrm{r}$. Socjaliści zdobyli z kolei powszechny rozgłos z chwilą utworzenia Galicyjskiej Partii Robotniczej (7 XI 1890), przemianowanej następnie na Socjalno-Demokratyczną Partię Galicji (SDPG, 1892).

63 I. Daszyński, Pamiętniki..., s. 27. Zob. też: idem, Szlachetczyzna a odrodzenie Galicyi, Lwów 1899.

64 Za: S. Lam, Życie wśród wielu, Warszawa 1968, s. 91; S. Wasylewski, op. cit., s. 257.

65 Przeglad. Wybory, „Naprzód”, 26 IX 1895.

66 [b.t], „Podolanin”, 18 IV 1901.

67 W. Witos, Moje wspomnienia, Warszawa 1981, s. 141. 
ludowcom pisał: „kiedyś szlachta rzeczywiście była winna wyzyskowi chłopów, ale to minęło i już szlachcic nie grzeje sobie rąk we wnętrznościach chłopa, wręcz przeciwnie, jest bardzo wielu takich, którzy ludowi w każdej chwili z radą, pomocą, lekarstwem, wstawiennictwem u władzy chętnie i bezinteresownie spieszą" ${ }^{68}$. Agitatorzy ludowi według Pinińskiego żerowali na biedzie wiejskiego ludu i na braku należytej łączności między dworem a wsią. Dalsze bagatelizowanie problemu mogło - jak konkludował hrabia - zakończyć się tragedią warstwy szlacheckiej. Same idee rozwoju wsi nie były obce ziemiaństwu wschodniogalicyjskiemu. Świadczyła o tym praca społeczna podejmowana na prowincji. Wyobrażano sobie jednak, że jedyną drogą do realizacji chłopskich postulatów była współpraca z dworem, nie zaś poparcie dla wieców i domorosłych agitatorów.

Socjalistów również oskarżano o manipulację ubogą ludnością, która - jak głosiła anonimowa broszura wydana w 1906 roku w Krakowie - ,jest leniwa i czeka tylko na rewolucję" ${ }^{\circ 9}$. Ataki Daszyńskiego na forum austriackiego parlamentu często odpierał Wojciech hr. Dzieduszycki. Dla niego socjalizm (podobnie jak dla hr. Pinińskiego hasła ludowców) był destrukcyjną siłą, prowadzącą do likwidacji elity intelektualnej i kulturalnej, a wszystkie obietnice wiecowe - mrzonką i ogłupianiem ludu ${ }^{70}$.

\section{Działalność ziemian na rzecz uzdrowienia majątków w Galicji Wschodniej}

Jak już zaznaczono, problemy ziemiaństwa wynikały bezpośrednio ze specyfiki narodowościowej terytorium Galicji Wschodniej i jej niskiego poziomu cywilizacyjnego. Pierwsze symptomy kryzysu były zauważalne już w połowie XIX wieku, jednak dopiero schyłek tego stulecia, a wraz z nim pierwsze niepowodzenia polityczne konserwatystów, skłoniły ich do działań na rzecz wzmocnienia warstwy większych posiadaczy. W 1895 roku Stanisław hr. Dzieduszycki w broszurze Czego ziemiaństwu potrzeba wymieniał jako najpilniejsze: stworzenie jasnego programu polityki krajowej względem gospodarki, organizację kredytu rolniczego oraz ukrócenie monopolu niektórych faktorów w handlu zbożowym ${ }^{71}$.

Wobec agitacji narodowców ukraińskich dwory szlacheckie na wschodzie kraju zaczęto z kolei nazywać ,pposterunkami służby narodowej”, a ich mieszkańców obrońcami polskich tradycji i patriotyzmu. Ziemiaństwo otrzymało w ten sposób misję utrzymania polskości na tych obszarach. Właściciel majątku Konty, Władysław Gniewosz, w 1895 roku pisał: „kto zna nasze stosunki i uczciwie się na nie zapatruje, ten przyzna, że dobro ojczyzny naszej jest absolutnie związane u nas z utrzymaniem

\footnotetext{
${ }_{68}$ M. Piniński, W sprawie ruchu ludowego. Szlachcic wiejski galicyjski (szkic społeczny), Lwów 1900, s. 9.

69 Socjalizm a wieś. Napisat Ziemianin, Kraków 1906, s. 16.

70 K.K. Daszyk, Osobliwy Podolak. W kręgu myśli historiozoficznej i spoleczno-politycznej Wojciecha hr. Dzieduszyckiego, Kraków 1993, s. 45-47. Ciekawe spostrzeżenia na temat rozwoju myśli lewicowej znajdują się także w: W. Dzieduszycki, Doką nam iść wypada, Brody 1910.

${ }^{71}$ Fragmenty opublikowane w: „Gazeta Narodowa”, 18 IX 1895.
} 
się przy ziemi. Jesteśmy glebae adscripti, to jest narodowem naszem prawem i obowiązkiem, a nie masz prawa, które byłoby wyższem"72.

Prawdziwym impulsem do mobilizacji ziemian do działania na polu społecznym stały się wielkie strajki rolne w 1902 roku. Od schyłku XIX wieku ukraińscy narodowcy zaczęli propagować organizację strajków chłopskich jako formę sprzeciwu wobec niesprawiedliwych warunków panujących na wsi galicyjskiej ${ }^{73}$. Do pierwszych, lokalnych wystąpień chłopskich doszło wiosną 1900 roku w powiatach Borszczów i Czortków. Kolejna fala strajków wybuchła w lecie 1902 roku i odbiła się szerokim echem w całej monarchii, poważnie wpływając na wzrost napięcia w relacjach polsko-ukraińskich. Od czerwca do końca sierpnia strajki objęły w sumie 28 powiatów Galicji Wschodniej, przede wszystkim Zbaraż, Tarnopol, Skałat, Husiatyn, Trembowlę, Czortków, Buczacz, Zaleszczyki ${ }^{74}$. W sumie zanotowano ponad 490 wystąpień, w których brało udział - według danych zebranych przez ukraińskiego socjalistę Semena Wityka - około 150000 chłopów. Włościanie żądali większej płacy za roboty dorywcze u ziemian, skrócenia czasu pracy, bezpłatnego udostępnienia pastwisk, lasów i dróg dworskich, sprzeciwiali się sprowadzaniu polskich robotników rolnych oraz wykorzystywaniu w polu żniwiarek. Na wiecach pojawiły się także obecne od jakiegoś czasu hasła polityczne - postulaty powszechnego prawa wyborczego oraz podziału Galicji na część polską i ukraińską ${ }^{75}$.

Sytuacja ekonomiczna dworów ziemiańskich uległa dalszemu pogorszeniu, zważywszy na fakt, że lata poprzedzające wystąpienia były bardzo nieurodzajne z powodu suszy i powodzi. Przede wszystkim jednak strajki dały opozycji mocny argument w dalszej walce o władzę w zdominowanej przez polskie sfery wyższe Galicji. Potwierdziła to dyskusja podczas jesiennych obrad parlamentu wiedeńskiego. Konserwatystów w ostrych słowach zaatakowali socjaliści Ignacy Daszyński i Ernest Breiter oraz przywódca ukraińskich narodowców Julian Romańczuk. Przedstawiając sprawozdanie z przebiegu wystąpień Romańczuk wskazywał na liczne nadużycia ze strony żandarmów i wojska: gwałty, rabunki i samosądy. Daszyński obrazowo przedstawił kolejne dowody na ucisk i nędzę galicyjskiego chłopstwa, zwracając się wprost do poszczególnych właścicieli ziemskich. Liczne ataki opozycji odpierali ziemianie, między innymi Dawid Abrahamowicz, Stefan Moysa-Rosochacki, Władysław hr. Czaykowski i Wojciech hr. Dzieduszycki. Poseł W. hr. Czaykowski w patetycznych słowach apelował o wznowienie współpracy między dworem a wsią, zapewniając: „,nie chcemy wcale walki z bratnim narodem ruskim, jesteśmy tego samego pochodzenia. Nasza szlachta: Szeptyccy, Dzieduszyccy - jest ruskiego pochodzenia. Czaykowscy jedni są Polakami, drudzy Rusinami. Przez Opatrzność i historię przeznaczeni jesteśmy na to, abyśmy żyli zgodnie ze sobą w naszej wspólnej ojczyźnie

72 Przed wyborami sejmowemi (o broszurze Wt. Gniewosza), „Gazeta Narodowa”, 14 IX 1895.

73 J. Rozwadowski, Ruskie bezrobocie..., s. 3.

74 Стрейк, „Громадський Голос”, lipiec 1902, cz. 13.

75 Хлопські стрейкі, „Діло”, 15 VI 1902; Хлопські стрейкі в Східній Галичині, „Діло”, 11 VII 1902; По стрейках, „Діло”, 26 VIII 1902. 
i zgodnie pracowali dla dobra państwa i naszego kraju"76. W podobnym tonie przemawiali inni przedstawiciele konserwatystów, jednak ataki ze strony opozycji nie ustawały. Semen Wityk w głośnej broszurze dedykowanej włościanom biorącym udział strajkach nazwał ziemiaństwo „garstką brutalnych wyzyskiwaczy, nędznych gnębicieli, dla których talizmanem duszy jest renta gruntowa i dochód z zagrabionych lasów”, pisał również, że ich władza „oparta jest na bagnetach austriackich żandarmów i wyborczej korupcji”"77.

Istotne, że wydarzenia z roku 1902 przyczyniły się do wzrostu zainteresowania ziemiaństwa (zwłaszcza młodszego pokolenia) poglądami reprezentowanymi przez Narodową Demokrację. Spowodowało to dalszą polaryzację polsko-ukraińskiego konfliktu i zamknięcie się na argumenty drugiej strony. Polem wspólnego działania ziemian stały się pozostające pod wpływem endecji Towarzystwo Kółek Rolniczych, Towarzystwo Szkoły Ludowej, Towarzystwo Gimnastyczne „Sokół” oraz inne polskie organizacje gospodarcze i kulturalno-oświatowe, które u progu 1903 roku posiadały w Galicji Wschodniej ogółem ponad tysiąc oddziałów. Ich domeną była między innymi organizacja wykładów, czytelni, szkół, kółek samokształceniowych, a także obchodów rocznicowych i wieców patriotycznych ${ }^{78}$. Wśród ziemian, którzy aktywnie działali w Galicji Wschodniej na rzecz tych organizacji, można wymienić Jana Rozwadowskiego, Witolda ks. Czartoryskiego, Tadeusza Cieńskiego, Leszka Cieńskiego, Włodzimierza Bolestę-Kozłowskiego, Albina Rayskiego, Artura Zarembę-Cieleckiego ${ }^{79}$.

Do listy organizacji społecznych dołączyły także tworzone przez lokalnych ziemian i polską inteligencję tak zwane Polskie Organizacje Narodowe (PON), powstające pod auspicjami konserwatywnego Centralnego Komitetu Wyborczego dla Galicji Wschodniej ${ }^{80}$. Ich zadaniem stała się przede wszystkim praca na rzecz „,repolonizacji” Galicji Wschodniej. W październiku 1902 roku na zjeździe ziemian we Lwowie uchwalono potrzebę włączenia szerokiego kręgu społeczeństwa polskiego do działań nad szerzeniem oświaty, wiary rzymskokatolickiej, moralności. Wezwano do

76 Sprawy sejmowe, „Gazeta Narodowa”, 12 XI 1902. Zob. też: J. Teodorowicz, Z ostatnich doświadczeń. Uwagi po strejkach, Lwów 1903.

77 S. Wityk, Precz z Rusinami, za San z Polakami!, Lwów 1903, s. 2-3.

78 J.W. Kosmowska, Towarzystwo Szkoty Ludowej w Galicji, Warszawa 1917, s. 5-12; S. Srokowski, Jak lud polski wchodził w Polskę. Garść wspomnien o pracy oświatowej na zachodniem Podolu w latach 1903-1914, Tarnopol 1928, s. 14-15. J. Zamorski, Praca oświatowa i narodowa na Podolu Galicyjskim. Wspomnienia, „Przegląd Wszechpolski” 1924, nr 5-9, s. 419-425, 492-505, 581-592, 641-667, 752-759.

79 Zob. A. Wątor, Spis większych właścicieli ziemskich należacych do Stronnictwa Demokratyczno-Narodowego w dzielnicy austriackiej, „Galicja. Studia i materiały” 2015, nr 1, s. 328-342.

80 Szerzej: M. Semczyszyn, Galicyjskie wybory..., s. 169-181; eadem, Specyfika kampanii wyborczych do Sejmu Krajowego i Rady Państwa w Galicji Wschodniej w latach 1867-1901 [w:] Między polityka, historia a pamięcia historyczna. Studia z dziejów Polski okresu porozbiorowego, red. W. Łazuga, S. Paczos, Poznań 2015, s. 77-96; O. Arkusza, Українсько-польські відносини у Східній Галичині на початку XX століття: Акція Влодзімєжа Козловського 1902-1903 років, „Вісник Львівського університету. Серія історична” 2002, nr 37, cz. 1, s. 268-314; O. Arkusza, M. Mudryj, XIX-wieczna arystokracja polska w Galicji Wschodniej wobec ruskich (ukraińskich) aspiracji narodowych, „Krakowskie Pismo Kresowe" 2012, s. 145-171. 
umacniania świadomości narodowej wśród ludu i jednocześnie propagowano slogan pracy nad zgodą pomiędzy Polakami i Ukraińcami na zasadach historycznej jedności obu narodów. Akcja PON oznaczała, że między polskimi a ukraińskimi organizacjami o profilu politycznym, gospodarczym i kulturalno-oświatowym rozgorzała zacięta rywalizacja „o rząd dusz” w Galicji Wschodniej. Aktywizacja sfer ziemiańskich i inteligenckich zrzeszonych w PON potęgowała antagonizm polsko-ukraiński. Ukraińscy narodowcy w odpowiedzi na polskie zjazdy powiatowe rozpoczęli mobilizację ukraińskich stowarzyszeń. Głoszono podobne hasła jak na polskich wiecach narodowych: potrzebę ochrony ziemi, promocji ukraińskiego handlu i przemysłu, a nade wszystko ukraińskich organizacji kulturalno-oświatowych ${ }^{81}$.

Początkowo akcja stanowiła potężny impuls dla polskich stowarzyszeń i spotkała się z żywym odzewem ze strony społeczeństwa polskiego. Na zjazdy, których do lata 1903 roku odbyło się ponad 40, przychodziły tłumy zainteresowanych, tworzono kilkudziesięcioosobowe komitety mężów zaufania, organizowano zbiórki pieniędzy na cele oświatowe, budowę kościołów, kaplic i szkół. Inicjatywa zyskała poparcie namiestnika Leona hr. Pinińskiego i arcybiskupa Józefa Bilczewskiego ${ }^{82}$, a także księży rzymskokatolickich włączających się w pracę komitetów lokalnych. Rozpoczęto również działania mające na celu zahamowanie parcelacji i kierowanie sprzedażą ziemi, tak aby trafiała $\mathrm{w}$ ręce polskich gospodarzy. 5 marca 1903 roku na zjeździe ziemian Galicji Wschodniej uchwalono stworzenie funduszu na cele obrony przed strajkami ${ }^{83}$. W 1902 roku powołano Towarzystwo Ochrony Ziemian, a w 1904 roku Towarzystwo Wzajemnej Pomocy Ziemian przy Towarzystwie Kredytowym Ziemskim z Albinem Rayskim na czele. W wyniku akcji zwiększone zainteresowanie odnotowały Towarzystwo Szkoły Ludowej i oddziały „Sokoła”. Powstawały różne lokalne organizacje o profilu narodowym, takie jak Okręgowa Organizacja dla Ochrony Narodowości Polskiej czy Młodzież Polska w Stanisławowie ${ }^{84}$.

Szczegółowe sprawozdania z przebiegu akcji PON przechowywane w zasobie Biblioteki imienia Wasyla Stefanyka we Lwowie dowodzą jednak, że to silne (zwłaszcza w pierwszych miesiącach) ożywienie nie wszędzie przyniosło oczekiwane rezultaty. Odsłoniło za to rozmiar problemów Polaków w Galicji Wschodniej. Działacze lokalnych komitetów przekazywali w korespondencji nadsyłanej do przewodniczącego PON, Włodzimierza Bolesty-Kozłowskiego, paraliżujące informacje. W powiecie bohorodczańskim liczbę polskiej ludności oceniono na ,3\%, realnie - 0,5\%”, w powiecie sokalskim w języku polskim porozumiewało się nie więcej niż 10\% społeczności, podobnie w Bóbrce. „Tysiące dusz przechodzi na ruski obrządek, księża

81 Ibidem, s. 297-302.

82 Lwowska Narodowa Naukowa Biblioteka Ukrainy im. Wasyla Stefanyka (dalej: LDNBU Stef.), Archiwum Włodzimierza Kozłowskiego, f. 59, teka nr 386, List Adolfa Cieńskiego do Włodzimierza Kozłowskiego z 26 lutego 1903 r., fascykuł, wiązka III, b.p.

83 O. Arkusza, op. cit., s. 291.

84 Państwowe Historyczne Ukraińskie Archiwum we Lwowie (dalej: CDIAL), f. 810, op. 1, spr. 21, Sprawozdania z czynności Wydziału Towarzystwa „Młodzież Polska” w Stanisławowie za rok administracyjny 1903, 1904 oraz 1905, k. 4-65. Zob. też: A. Wątor, Na galicyjskim Podolu. Praca narodowa i oświatowa w relacjach uczestników do roku 1914, Szczecin 2018. 
obojętni”, „ruszczeją nawet kolonie niemieckie” (powiat turczański) ${ }^{85}$. Żalono się na postawy ziemian, którzy uczęszczali do cerkwi (Jerzy hr. Baworowski), wspierali finansowo ukraińskie duchowieństwo i stowarzyszenia (ks. Sapieżyna) i zatrudniali ukraińskich oficjalistów dworskich (Roman hr. Potocki). Narzekano także na kondycję społeczeństwa i „wieloletnie zaniedbania na polu patriotycznym" ${ }^{\text {"86. }}$.

Retoryka „oblężonej twierdzy” w stosunku do dworów ziemiańskich w Galicji Wschodniej pozostała stałym elementem konserwatywnej publicystyki przed I wojną światową. W 1907 roku pisano: „póty nas, póty ziemię mamy pod nogami. Tej ziemi bronić, tę ziemię zatrzymać, to nasz obowiązek [...]. Dwory dla przyszłości narodu, jak i dla równowagi społecznej są historyczną koniecznością [...], posiadanie dostatków, majątków, ziemi to włodarstwo boże, z którego zdać należy rachunek przed krajem" $"$.

Powolny zmierzch hegemonii warstwy ziemiańskiej miał w Galicji Wschodniej swoje ideologiczne konotacje, które w odróżnieniu od zachodniej części kraju koronnego nie dotyczyły jedynie problemów „klasowych”. Na terenie „ukrainizującej się” („,zruszczonej” - jak mawiali współcześni) Galicji Wschodniej polityczna i społeczna emancypacja chłopstwa zyskała dodatkowy, dominujący na tym obszarze czynnik etniczny. W dobie rodzącego się nowoczesnego nacjonalizmu konflikty społeczne między dworem a wsią przybrały narodowościowy charakter. W taki oto sposób u progu XX wieku ziemiaństwo Galicji Wschodniej stanęło przed poważnym problemem polsko-ukraińskiego sporu, którego złożoność odczuwano na tych terenach przez następne dziesięciolecia.

\section{BIBLIOGRAFIA}

\section{Źródła archiwalne}

Lwowska Narodowa Naukowa Biblioteka Ukrainy im. Wasyla Stefanyka, Lwów Państwowe Historyczne Ukraińskie Archiwum, Lwów

Zakład Narodowy im. Ossolińskich, Wrocław

85 LDNBU Stef., Archiwum Włodzimierza Kozłowskiego, f. 59, teki nr 401 i 402, Sprawozdania z powiatów Turka, Sokal, Skałat, Bobrka, Bohorodczany [1904], k. 4, 7, 47 i 88, 223.

${ }^{86}$, ,...] pole działania osobliwie wśród ludu wiejskiego wdzięczne. Z mieszczaństwem bieda, inteligencja miejska ofiarna, dość patriotyczna, ale zapita i zagrana w karty. Obywatelstwo [ziemiaństwo przyp. M.S.] apatyczne, leniwe, nieofiarne. Wymaga ostrych ataków". CDIAL, f. 810, op. 1, spr. 21, List Tadeusza Cieńskiego do [Witolda Czartoryskiego] z 13 kwietnia 1905 r. (Lozanna), k. 28.

87 Zwiazek ziemian, „Gazeta Narodowa”, 11 IX 1907. 


\title{
Prasa
}

\author{
„Dziennik Polski” \\ "Gazeta Narodowa" \\ „Naprzód” \\ „Podolanin" \\ „Діло” 1902 \\ „Громадський Голос” 1902
}

\section{Wydawnictwa urzędowe, broszury}

Czartoryski W., Kółka ziemian, Kórnik 1912.

Daszyński I., Szlachetczyzna a odrodzenie Galicyi, Lwów 1899.

Dubanowicz E., Kurya wielkiej własności, Lwów 1913.

Dunin-Borkowski J., Spis nazwisk szlachty polskiej, Lwów 1888.

Głąbiński S., Ludność polska w Galicji Wschodniej, Lwów 1903.

Kasznica S., Nadobnik M., Najważniejsze wyniki spisu ludności i spisu zwierząt domowych wedtug stanu z 31 grudnia 1910 r., „Wiadomości Statystyczne o Stosunkach Krajowych" 1911, t. 24, z. 1.

Pilat T., Najważniejsze wyniki spisu ludności z 31 grudnia 1890, „Wiadomości Statystyczne o Stosunkach Krajowych" 1891, t. 13.

Pilat T., O stosunkach własności tabularnej w Galicji a w szczególności w obwodzie sądowym tarnopolskim. Wykład na posiedzeniu XXIII Rady Ogólnej c.k. galicyjskiego Towarzystwa Gospodarczego, Lwów 1888.

Rozwadowski J., Obrona Ziemi. Odczyt wygłoszony w Związku Kół Ziemianek we Lwowie dnia 7 marca 1912 r., Kraków 1912.

Rozwadowski J., Ruskie bezrobocie w 1902 roku. Uwagi o jego terenie, Lwów 1904.

Skorowidz dóbr tabularnych w Galicyi z Wielkiem Księstwem Krakowskiem na podstawie najnowszych materiatów urzędowych, oprac. T. Pilat, Lwów 1890.

Słownik geograficzny Królestwa Polskiego i innych krain słowiańskich, t. II, Warszawa 1881.

Socjalizm a wieś. Napisat Ziemianin, Kraków 1906.

Stefczyk F., Licytacje sądowe większej posiadłości ziemskiej w Galicji 1876-1885, Kraków 1886.

Stefczyk F., Problem sejmowej reformy wyborczej w świetle statystyki ludnościowej i podatkowej, Lwów 1912.

Stupnicki H., Herbarz polski i imion spis zasłużonych w Polsce ludzi wszystkich stanów i czasów, ułożony porząkiem alfabetycznym na podstawie herbarza Niesieckiego i manuskryptów, t. I-III, Lwów 1855-1862.

Teodorowicz J., Z ostatnich doświadczeń. Uwagi po strejkach, Lwów 1903.

Wityk S., Precz z Rusinami, za San z Polakami!, Lwów 1903.

Ziemianin Ilustrowany. Kalendarz poświęcony sprawom rolnictwa i ogrodnictwa krajowego na rok 1898 wydany przez pierwszy galicyjski Dom Dla Ziemian, Lwów 1898. 


\section{Pamiętniki}

Chłędowski K., Pamiętniki, t. I-II, Kraków 1957.

Daszyński I., Pamiętniki, t. I, Warszawa 1957.

Głąbiński S., Wspomnienia polityczne, Pelpin 1939.

Jabłonowski L., Pamiętniki, Kraków 1963.

Kofler O., Żydowskie dwory. Wspomnienia z Galicji Wschodniej od początku XIX wieku do wybuchu I wojny światowej, Warszawa 1999.

Lam S., Życie wśród wielu, Warszawa 1968.

Longchamps de Berier B., Ochrzczony na szablach powstańczych. Wspomnienia (18841918), Wrocław 1983.

Mycielski A., Chwile czasu minionego, Kraków 1976.

Rosco-Bogdanowicz M., Wspomnienia, t. 1-2, Kraków 1959.

Srokowski S., Jak lud polski wchodzit w Polskę. Garść wspomnień o pracy oświatowej na zachodniem Podolu w latach 1903-1914, Tarnopol 1928.

Wasylewski S., Czterdzieści lat powodzenia. Przebieg mojego życia, Wrocław 1959.

Witos W., Moje wspomnienia, Warszawa 1981.

Zamorski J., Praca oświatowa i narodowa na Podolu Galicyjskim. Wspomnienia, „Przegląd Wszechpolski” 1924, nr 5-9.

\section{Opracowania}

Arkusza О., Українсько-польські відносини у Східній Галичині на початку ХХ століття: Акція Влодзімєжа Козловського 1902-1903 років, „Вісник Львівського університету. Серія історична" 2002, nr 37, cz. 1, s. 268-314.

Arkusza O., Mudryj M., XIX-wieczna arystokracja polska w Galicji Wschodniej wobec ruskich (ukraińskich) aspiracji narodowych, „Krakowskie Pismo Kresowe” 2012, s. 145-171.

Bujak F., Galicya, t. I: Kraj, ludność, społeczeństwo, rolnictwo, Lwów-Warszawa 1908.

Bujak F., Rozwój gospodarczy Galicji 1772-1914, Lwów 1917.

Buszko J., The Consequences of Galician Autonomy after 1967, „Polin: Studies in Polish Jewry" 2001, vol. 12: Focusing on Galicia: Jews, Poles and Ukrainians 1772-1918, s. 86-99.

Daszyk K.K., Osobliwy Podolak. W kręu myśli historiozoficznej i społeczno-politycznej Wojciecha hr. Dzieduszyckiego, Kraków 1993.

Dzieduszycki W., Dokąd nam iść wypada, Brody 1910.

Dzieduszycki W., Listy ze wsi, serya I, Lwów 1889.

Feldman W., Stronnictwa i programy polityczne w Galicji 1846-1906, t. I, Kraków 1907.

Franaszek P., Informator statystyczny do dziejów społeczno-gospodarczych Galicji. Rolnictwo w Galicji w dobie autonomii. Produkcja roślinna, cz. I, Kraków-Warszawa 1992.

Gąsowski T., Austriackie spisy ludności z lat 1869-1910, „Przeszłość Demograficzna Polski” 1981, t. 13 s. 37-48..

Gąsowski T., From Austeria to the Manor: Jewish Landowners in Autonomous Galicia, „Polin: Studies in Polish Jewry” 2001, vol. 12, s. 120-136

Górski A., Podolacy. Obóz polityczny i jego liderzy, Warszawa 2013.

Himka J.P., Dimensions of a Triangle: Polish-Ukrainian-Jewish Relations in Austrian Galicia, „Polin: Studies in Polish Jewry” 2001, vol. 12: Focusing on Galicia: Jews, Poles and Ukrainians 1772-1918, s. 25-48. 
Hoff J., Mieszkańcy małych miast Galicji Wschodniej w okresie autonomicznym, Rzeszów 2005.

Kosmowska J.W., Towarzystwo Szkoły Ludowej w Galicji, Warszawa 1917.

Ludwikowski R., Szkice na temat galicyjskich ruchów i myśli politycznej (1848-1892), Warszawa 1980.

Łazuga W., Kalkulować... - Polacy na szczytach C.K. Monarchii, Poznań 2013.

Ostrożyński W., Galicyjskie Towarzystwo Kredytowe ziemskie. Jego powstanie i pótwiekowy rozwój, Lwów 1892.

Pawłowski S., Ludność rzymsko-katolicka w polsko-ruskiej części Galicji, Lwów 1919.

Piniński M., W sprawie ruchu ludowego. Szlachcic wiejski galicyjski (szkic społeczny), Lwów 1900.

Piszczek S., Ormianie w życiu politycznym Galicji w latach 1861-1914, „Przemyskie Zapiski Historyczne" R. 14/15, 2003/2005, s. 109-137.

Pucek Z., Więź społeczna w wielokulturowej Galicji, „Państwo i Społeczeństwo” R. 8, 2008, nr 1, s. 59-70.

Rapacki W., Ludność Galicji, Lwów 1874.

Semczyszyn M., Galicyjskie wybory. Działalność Centralnego Komitetu Wyborczego dla Galicji Wschodniej 1867-1906, Warszawa 2014.

Semczyszyn M., Specyfika kampanii wyborczych do Sejmu Krajowego i Rady Państwa w Galicji Wschodniej w latach 1867-1901 [w:] Między polityka, historia a pamięcia historyczna. Studia z dziejów Polski okresu porozbiorowego, red. W. Łazuga, S. Paczos, Poznań 2015.

Semczyszyn M., Społeczno-polityczne postawy ziemiaństwa wschodniogalicyjskiego w świetle lwowskiej ,, Gazety Narodowej” (1886-1914) [w:] Spoleczeństwo - polityka kultura. Studia nad dziejami prasy w II Rzeczypospolitej, red. T. Sikorski, Szczecin 2006.

Skwara J., Konserwatyści wschodniogalicyjscy - podolacy wobec kwestii ukraińskiej w okresie namiestnictwa Michała Bobrzyńskiego 1908-1913, „Rocznik Historyczno-Archiwalny" 1996, t. 11, s. 21-38.

Soboń M., Polacy wobec Żydów w Galicji doby autonomicznej w latach 1868-1914, Kraków 2011.

Stauter-Halsted K., The Nation in the Village: The Genesis of Peasant National Identity in Austrian Poland 1848-1914, New York 2004.

Szymczak D., Między Wiedniem, Lwowem a Siemianówka. Dawid Abrahamowicz w życiu polityczno-społecznym Galicji i monarchii habsburskiej [w:] Znani i nieznani dziewiętnastowiecznego Lwowa. Studia i materiaty, t. 4, red. L. Michalska-Bracha, M. Przeniosło, Kielce 2014.

Śliż M., Galicyjscy Żydzi na drodze do równouprawnienia 1848-1914. Aspekt prawny procesu emancypacji Żydów w Galicji, Kraków 2006.

Ślusarek K., Włościańscy i niewłościańscy mieszkańcy wsi galicyjskiej w XIX wieku, „Zeszyty Naukowe Uniwersytetu Jagiellońskiego. Prace Historyczne” 1999, z. 126, s. 117124.

Teodorowicz L., Nieco o heraldyce i rodach Ormian Polskich, Lwów 1925.

Tereszczenko J., Галийький консерватизм в контексті Українсько-польських відносин в Австро-Угорщині (друга половина XIX - початок XX ст.), „Ucrainica-Polonica” 2007, t. 1 , s. 21-36.

Ustrzycki M., Pomiędzy konserwatyzmem a nacjonalizmem. Podolacy wobec kwestii narodowej na wsi wschodniogalicyjskiej na przełomie XIX i XX wieku (do 1908 r.), „Przegląd Wschodni" 1999, s. 477-498. 
Ustrzycki M., Ziemianie polscy na Kresach 1864-1914. Świat wartości i postaw, Kraków 2006.

Wątor A., Na galicyjskim Podolu. Praca narodowa i oświatowa w relacjach uczestników do roku 1914, Szczecin 2018.

Wątor A., Polityczna aktywność wschodniogalicyjskich konserwatystów w świetle stosunków polsko-ukraińskich w Galicji na przełomie XIX i XX wieku [w:] Polska-Ukraina: historia, polityka, kultura. Materiały międzynarodowej konferencji naukowej, red. S. Zabrowarny, Szczecin-Warszawa 2003.

Wątor A., Spis większych właścicieli ziemskich należacych do Stronnictwa Demokratyczno-Narodowego w dzielnicy austriackiej, „Galicja. Studia i materiały” 2015, nr 1, s. 328 342.

Wątor A., Ziemianin-polityk Tadeusz Cieński 1856-1925. Z dziejów konserwatyzmu wschodniogalicyjskiego, Szczecin 1997. 